\title{
THE CORRUPTION AND HUMAN DEVELOPMENT TO THE ECONOMIC GROWTH OF OIC COUNTRIES
}

\author{
Yusuf Kurniawan ${ }^{a}$ \\ Ririn Tri Ratnasari ${ }^{b}$ \\ Hindah Mustika ${ }^{c}$ \\ a,b Islamic Economics Department, Faculty of Economics and Business, University of Airlangga \\ c Management Department, Sekolah Tinggi IImu Ekonomi Indonesia (STIESIA) Surabaya \\ Email: yusuf.kurniawan-2018@pasca.unair.ac.ida; ririnsari@feb.unair.ac.id ${ }^{b}$; \\ indah.mustika08@gmail.com ${ }^{c}$
}

\begin{abstract}
ARTICLE HISTORY
Received:

5 July 2020

Revised:

30 October 2020

Accepted:

29 November 2020

Online available:

11 December 2020

Keywords:

Corruption Perception Index,

Human Development

Index,

Gross Domestic

Product,

Organization of Islamic

Cooperation (OIC)

*Correspondence:

Name:

Ririn Tri Ratnasari

E-mail:

ririnsari@feb.unair.ac.id

This paper aims to estimate the effect of corruption (represented by data of Corruption Perception Index) and human development (represented by data of Human Development Index) on the economic growth (represented by data of Gross Domestic Product) in 44 (forty-four) countries who join the Organization of Islamic Cooperation (OIC). this paper uses multiple linear regression with panel data of Corruption Perception Index from transparency.org, Human Development Index from United Nations Development Program (UNDP) and Gross Domestic Product from World Bank. The 10 years range of data (2009-2018) finds the Corruption Perception Index does not have a significant effect on the economic growth, but The Human Development Index has a positive significant effect on the economic growth or Gross Domestic Product. It can be seen that the commitment of OIC countries in human development is on the right path, since they are in line with their economic growth rates. When viewed together, the Corruption Perception Index and the Human Development Index have a simultaneous influence on the economic growth. So, this result is important to help the OIC as additional references to their Annual Summit or Conference to focus more on Human Development strategy to enhance the economic growth.
\end{abstract}

\section{INTRODUCTION}

The discussion about economic growth is always interesting, economic growth according to Arsyad (2016) is an increase in Gross Domestic regardless of whether the increase is greater or smaller than the increase in population growth. Gross Domestic Product is the standard proportion of the added value through the creation of products and enterprises in a nation during a specific period. All things considered, including also the quantification of payment acquired from that creation, or the aggregate sum spent on final goods and services (OECD, 2020). The level of Gross Domestic Product is 
apparently caused by various factors, ranging from investment, labor (Sulaksono, 2015), infrastructure (Maryaningsih et al., 2014), fiscal instruments (Muharman \& Maski, 2013), inflation rates (Karlina, 2017), foreign debt (Rachmadi, 2013), and the most interesting in economic growth is that it is influenced by the level of corruption in a country represented by Corruption Perception Index and the quality of human development, represented by Human Developmet Index (Fajar \& Azhar, 2018).

Based on Blackburn et al. (2011), it is clear that corruption inhibits or impedes economic movements by affecting the effectiveness and efficiency of resources in the economy. Many economists and studies view corruption as a main obstacle to development. To see the level of the corruption in a country, see the figures from the Corruption Perception Index issued by transparency.org. The Corruption Perception Index is a composite indicator that combines various sources of information on corruption, so that it can be used as a comparison for the level of corruption in each country. The Corruption Perception Index data uses a scale from 0 to 100. If a country's Corruption Perception Index is getting smaller towards " 0 " then the level of corruption in that country is very high, and if a country's Corruption Perception Index is getting higher or goes to "100" then that country has a good level of corruption or is clean from corruption. In its development, the value of the issued Corruption Perception Index has succeeded in encouraging countries that have low Corruption Perception Index to be motivated to improve the cleanliness of their country from corruption cases.

The second factor that often affects a country's Gross Domestic Product growth is the quality of human development in a country, and is usually indicated by the score of Human Development Index. The Human Development Report (HDR) (UNDP, 1990) begins to be published by Mahbub Alhaq, he compiles the report inspired by a nobel winner, Amartya Sen, who creates a work on Human Capabilites (Sen, 1985). After the making of Human Development Report (HDR) by Mahbub Alhaq, the score of human development is always reported based on Human Development Index published every year by United Nations Development Programme (UNDP). This scoring is always used as the fundamental or basis for the performance of human development assessment (Mangaraj \& Aparajita, 2020).

Human Development Index is a tool used to assess the level of welfare between countries and regions (Todaro, 2013). referring to UNDP, the Human Development Index is a reference for the process of developing people's choices, in the level of longevity and health, the level of education or school, and the reference for eligibility for life. Examples of developing other options considered to uphold the above choices include spaciousness for political choices, human rights, and also respect for personal rights (Ginting et al., 2008). The Human Development Index is also used as an aggregate guide that is influenced by health parameters that are representative of life expectancy, representative of education indicators with literacy rates, average length 
of schooling, and economic parameters that are representative of community purchasing power.

Human Development Index values range from 0 to 1 . The size is represented by three decimal places behind 0 , the more inclined it is to the number 1 , then there is a signal that human development is getting better. One of the benefits of Human Development Index is that a country or region can make a breakthrough to increase low income (Sasana, 2009). From this level of income, it can be related to the Gross Domestic Product that will be created by a country in combination.

In Islamic economics, corruption or riswah becomes the main prohibition in it (Irfan, 2016; Umam, 2013) even for the Human Development Index, it is often equated with sharia maqashid which has become a reference of the main objectives for the Islamic economic system (Hanif, 2018; Hasibuan et al., 2018). Therefore, it is interesting to examine the relationship between corruption, human development and economic growth represented by Gross Domestic Product in the Islamic world, especially those who are members of the Organization of the Islamic Conference (OIC).

The OIC was only aimed to correct the Palestinian conflict at the beginning, but after several decades of action, the OIC goal was finally added, now the OIC has become an international organization that becomes a forum for cooperation in various fields of politics, economics, social, culture, and science knowledge between Muslim countries throughout the world.

If we examine one by one, it turns out that the majority of OIC countries are developing countries, and not a few are poor countries. Therefore an appropriate way is needed to provide a solution to how the OIC countries should develop, especially in terms of economic growth.

The economic growth of the OIC countries in the 2009 - 2018 period was quite stable, indeed only a few experienced significant fluctuations, among others due to the state of war, starting from Palestine, Libya and Sierra Leone, and some caused by the drop in world oil and gas which caused the economic growth of rich countries such as Saudi Arabia, Qatar and the UAE to experience a slight shock (Mohanty et al., 2011).

Therefore, from this background, this study aims to provide advice to OIC countries to focus on handling corruption and increasing the Human Development Index so as to lift their economic growth that is still very far behind other countries (SESRIC, 2015), especially it can be used as a reference for suggestions in the annual summit/conferences they hold, because the majority of the population of the OIC countries have the ideology and worldview of Islam, whose teachings strongly prohibit acts of corruption and also highly uphold the empowerment (human development) of the followers.

the difference from previous studies compared to this research lies in the sample and also variables, both endogenous and exogenous variables. And the object of research is wider than the previous research which only focused on one relationship (partial), then a small sample coverage (between provinces and cities in Indonesia). the 
research focuses on four ASEAN countries (Indonesia, Malaysia, Thailand and the Philippines), and in this study, all countries that are members of the Islamic Cooperation Organization or OIC with a very long data range of ten years, between 2009 until 2018.

\section{LITERATURE REVIEW}

In this case, the basic theory used is the Klitgaard's theory of corruption. According to the theory, corruption is an abuse of authority that occurs in the public sector. The category of corruption that will be discussed is more towards state corruption, namely a large amount of state resources taken and misused by several state officials, especially those committed by political elites and government officials (Fajar \& Azhar, 2018). If it is used in Adam Smith's theory of economic growth, which states that economic growth depends on the factors of Natural Resources, Human Resources and existing capital (Sukirno, 1985), therefore if it is linked to corruption, then state capital can be reduced, and this, according to Adam Smith's theory, will be able to encourage a reduction in the rate of economic growth.

Corruption is the use of public sector positions for personal gain. For example, starting from bribery, embezzlement, collusion, nepotism (Bardhan, 1997). Another definition of corruption is the exchange of goods or services by bureaucrats in return for something that is not appropriate or something that is not reasonable (Sandholtz \& Koetzle, 2000).

In addition to the basic theory above, there are several studies that focus on the impact of the Corruption Perception Index on economic growth (represented by Gross Domestic Product) and also the Human Development Index on economic growth, but it is only limited to a partial relationship. Also in the scope or research area that is not broad enough.

Starting from a study conducted by Erum and Hussain (2019) that examined the effect of corruption and natural resource to economic growth in 43 members of OIC country. The result showed corruption impeded economic growth.

Study by Ertimi et al. (2019) examined the impact of corruption in 14 countries, and the result was the same (the result showed corruption had a negative impact on economic growth) also another study had a similar conclusion (Al Qudah et al., 2020; Anh et al., 2016; Gründler \& Potrafke, 2019; Ibrahim, 2020; Machoski \& de Araujo, 2020; Useche \& Reyes, 2020),

Research by Akman and A.H Sapha (2018) examined the effect of corruption on economic growth in Indonesia, he used a sample of 46 cities in Indonesia for his value or economic growth variables and used the overall Indonesian corruption data from the Corruption Eradication Commission (KPK) where the KPK also obtained the Corruption Perception Index data from the international corruption watchdog, 
transparency.org. As a result of the research, it turned out that the increase in Corruption Perception Index (fewer corruptions) did not make economic growth rise.

Research by Tseng (2020), also examined the effects of corruption on economic growth and the results were the same, namely that the decline in corruption in a emerging country, had no impact on economic growth, on the contrary, it concluded that not all corruption had a bad effect on the economy. Corruption which had the characteristic "speed money" had a positive effect on economic growth (FernándezTorres et al., 2018; Sasti \& Latrini, 2019; Shabbir et al., 2016; Tseng, 2020).

But there are also those who get different results, or by means of decreasing the level of corruption turns out to have a good impact on economic growth (Nawatmi, 2016) in Asia Pacific countries and also what has been studied by Fajar and Azhar (2018) in Southeast Asian countries (ASEAN).

Regarding the Human Development Index, Adam Smith's Growth Theory can be used as a basic reference. According to Adam Smith, there are two main aspects of economic growth. In the growth of economic output, Adam Smith observes three factors affecting the production side, the first is natural resources, the second is human resources and the third is the amount of capital (Sukirno, 1985). It is also supported by Neoclassical Growth Theory, which is delivered by Robert Solow and Trevor Swan. They believe that with technical progress and improvement in the quality of workers, they tend to increase incomes higher so that community demand will increase and so on (Suryana, 2000).

From Islamic economics perspective described by Chapra (2007), one of the most constructive ways to accelerate economic growth is to enable society and individuals to make the most of their creative and artistic abilities in a professional, productive and efficient manner.

In addition to the basic theory, there are many studies that discuss the impact of the Human Development Index on economic growth turns out that most of them mention the significant influence of Human Development Index on economic growth, starting from research conducted with a sample of one city by Kawulur et al. (2019); Susanto and Rachmawati (2013); and Izzah (2014), then within the scope of one country by Awad et al. (2014); Azeem et al. (2013); Ezkirianto and Alexandi (2018); Mahmood and Alkahtani (2018); and Viddy et al. (2019), then in scope of multinational area by Fajar and Azhar (2018); Qamruzzaman et al. (2020); and Tsaurai and Ndou (2019). The results from all of them state one similar conclusion: the Human Development Index positively influences the economic growth as represented by Gross Domestic Product growth. But, study by Feriyanto (2019) and Prawoto and Tri Basuki (2020) is different. The findings show that Human Development Index has a negative influence on economic growth.

Fajar and Azhar (2018) also combine the two exogenous variables of Corruption Perception Index and the Human Development Index on the economic growth of ASEAN countries and produce the conclusion that the two factors when combined 
have a positive influence related to the increase in economic growth in the countries of Southeast Asia.

Therefore in this study, we want to develop and combine the influence of the relationship between the Corruption Perception Index and the Human Development Index on economic growth in countries affiliated with the Islamic Development Bank or the OIC.

\section{RESEARCH METHODS}

The data used are 44 countries countries affiliated with the OIC. There are some countries that are not included, namely countries whose data are still blank at the World Bank such as data for Palestine, Somali and Syria. Also countries that are at war or are experiencing very high levels of fluctuations in economic growth such as Libya, because the existence of this war will have a direct impact on the economy of the country (Fanny et al., 2011).

The variables are three main data; economic growth data taken from Gross Domestic Product data released by the world bank as endogenous variables, then the Corruption Perception Index data released by transparency.org, and the Human Development Index issued by UNDP as an exogenous variable. The three data above were taken in a vulnerable period of ten years, starting from 2009 to 2018, because during that period, the world economic situation was quite stable and there was no impact of the global crisis.

Because this research has panel data, multiple linear regression aims to see the impact of exogenous variables on endogenous variables, because regression analysis is a method of identifying which variables have an impact on a topic of interest. The process of performing regression allows to confidently determine which factors are most important, which factors can be ignored, and how these factors influence each other. With the formula:

$$
G D P_{t}=\alpha+81\left(C P l_{i t}\right)+82\left(H D l_{i t}\right)+e
$$

Notes: GDP = Gross Domestic Product; $\alpha=$ constant; $\beta=$ regression coefficient; $\mathrm{CPI}=$ Corruption Perception Index; $\mathrm{HDI}=$ Human Development Index; $\mathrm{i}=$ country; $\mathrm{t}=$ time; e = standard error.

Therefore the following hypothesis is obtained:

$\mathrm{H}_{1}$ : CPI affects the GDP

$\mathrm{H}_{2}$ : HDI influences GDP

$\mathrm{H}_{3}$ : $\mathrm{CPI}$ and $\mathrm{HDI}$ simultaneously influence the GDP

The t-test aims to see the effect of exogenous variables partially on endogenous variables (Ghozali, 2016). This test uses a significance level of 0.05 ( $\alpha=$ $5 \%)$. This shows that the exogenous variable will get the value of $t$ in the critical area if the hypothesis is true 0.05 or $t$ arithmetic count is greater than $t$ table then $\mathrm{HO}$ is 
rejected, which means that there is an influence of exogenous variable on endogenous variables and vice versa.

The $f$-test aims to see the effect of all exogenous variables together on their endogenous variables. This test uses a significance level of $0.05(\alpha=5 \%)$. When the value is less than the significance or $5 \%(p<0.05)$ and $f$ statistic $>f$ table, it can be interpreted that there is a joint influence of all exogenous variables to their endogenous variables. $(F$ statistics $=f(k ; n-k)$

\section{RESULT AND ANALYSIS}

Based on the results of the t test that has been run, the following results are obtained:

Table 1

Result of t-Test

\begin{tabular}{lrrrrr}
\hline & \multicolumn{2}{c}{$\begin{array}{l}\text { Unstandardized } \\
\text { Coeffecients }\end{array}$} & $\begin{array}{l}\text { Standardized } \\
\text { Coeffecients }\end{array}$ & t & Sig. \\
\cline { 2 - 7 } & \multicolumn{1}{c}{ B } & Std. Error & Beta & & \\
\hline (Constant) & -257.047 & 60.522 & & -4.247 & .000 \\
IPK & 1.987 & 1.410 & .104 & 1.410 & .160 \\
IPM & 521.005 & 109.693 & .350 & 4.750 & .000 \\
\hline
\end{tabular}

Source: Data Processed

It can be seen that the results of the $t$ test produce a significance value for the Corruption Perception Index variable of 0.160 which means more than the alpha value or $>0.05$, indicating that the Corruption Perception Index variable has no partial effect on the endogenous variables of Gross Domestic Product. Then for the variable of Human Development Index has a significance result of 0.000 where it is less than alpha or $<0.05$, indicating that the Human Development Index variable affects the endogenous variables. With a coefficient of 521,005 it means that an increase in the Human Development Index in 1 unit of the index also increases the Gross Domestic Product by 521 million dollars. For negative constants $(-257,047)$ this does not matter as long as $X 1$ and $X 2$ cannot be equal to 0 because it is not possible to occur (Rietveld \& Sunaryanto, 1994). Therefore, $\mathrm{H} 1$ is rejected and $\mathrm{H} 2$ is accepted.

Table 2

Result of F Test

\begin{tabular}{lccccc}
\hline & Sum of Squares & Df & Mean Square & $\mathbf{F}$ & Sig. \\
\hline Regression & 1864893.29 & 2 & 932446.644 & 22.69 & $.000^{\text {b }}$ \\
Residual & 8914424.95 & 217 & 41080.299 & & \\
Total & 10779318.2 & 219 & & & \\
\hline
\end{tabular}

Source: Data Processed

For the $f$ test, the probability result is 22,698 with a significance of 0,000 . Therefore if compared with $f$ table, with $D F=2$. You will have 2.32 , where $t$ arithmetic count $>\mathrm{t}$ table. Therefore the Corruption Perception Index and the Human Development Index have a simultaneous influence on the Gross Domestic Product. Therefore $\mathrm{H} 3$ is accepted. 
Therefore, the above results are not in line with the basic theory of corruption. The basic theory of corruption states that it can cause economic growth to be hampered or impeded, because state capital is taken by corruptors, it should inhibit the rate of economic growth (Al Qudah et al., 2020; Anh et al., 2016; Ertimi et al., 2016; Erum \& Hussain, 2019; Gründler \& Potrafke, 2019; Ibrahim, 2020; Machoski \& de Araujo, 2020; Useche \& Reyes, 2020). The results of this study are the opposite, the corruption has no effect on economic growth. supporting research conducted by Tseng (2020) concludes that corruption in a emerging country has no impact on economic growth, it is concluded that not all corruption has a bad effect on the economy (Fernández-Torres et al., 2018; Sasti \& Latrini, 2019; Shabbir et al., 2016; Tseng, 2020). Corruption with the characteristic of "speed money" or "grease the wheel" has a positive effect on economic growth. After a closer look, this is indeed reasonable, because in the world Corruption Perception Index ranking, the fact is that the top 10 (most corrupt countries) are $80 \%$ from OIC countries, namely Somalia, Syria, Sudan, Yemen, Afghanistan, Burundi, Libya and Iraq.

Then for the results of the Human Development Index which are in line with the theory of economic growth presented by Adam Smith and the Neoclassical Growth Theory presented by Robert Solow and Trevor Swan, and Islamic Economic's perspective by Chapra where Human Development Index are very influential on economic growth. In addition, the results of this study also support the research conducted by Awad et al. (2014); Azeem et al. (2013); Ezkirianto and Alexandi (2018); Fajar and Azhar (2018); Izzah (2014); Mahmood and Alkahtani (2018); Qamruzzaman et al. (2020); Susanto and Rachmawati (2013); Tsaurai and Ndou (2019); Viddy et al. (2019). The results of all of them state one similar conclusion: the Human Development Index significantly influences the economic growth as represented by the Gross Domestic Product growth. This further strengthens the common thread that one indicator of increasing Gross Domestic Product is by increasing the Human Development Index. OIC countries must have a joint agreement to eradicate corruption by increasing transparency or openness, providing strict penalties for perpetrators and increasing public participation are ways that can be taken by them and all elements of society to reduce corruption in the OIC countries, especially in countries that are still in a state of poverty or conflict. Also maintaining human development programs such as in education, health, human rights enforcement, and others. It has been proven in many studies that the human development always has a positive and significant impact on Gross Domestic Product growth and overall economic growth should be presented continuously start from main result to the supporting results. 


\section{CONCLUSION}

The Regression results from 44 OIC member countries and in the last ten years (2009 - 2018) show that the Corruption Perception Index as an indicator of corruption in OIC countries does not affect Gross Domestic Product or economic growth. However, the Human Development Index has a positive and very significant effect on the Gross Domestic Product. Therefore, it can be seen that the commitment of the OIC countries in human development is on the right path, because it is in line with their economic growth rates. When viewed simultaneously, the Corruption Perception Index and the Human Development Index have a simultaneous influence on the economic growth. So, this result is important to help the OIC as additional references for their Annual Summit or Conference.

Further researchers are advised to continue studying OIC countries, but by categorizing in advance, starting from OIC countries specifically producing oil, OIC countries specifically in the Asian region, OIC countries specifically in the African region. In addition, other exogenous variables can also be added, ranging from inflation, total debt, total savings, export-import and other macro variables. Because by categorizing and adding them, it can make the results of research more comprehensive and a lot. Another advise is detailing the Human Development Index's factor for exogenous variables, such as scores of the education, scores of health, and also about a decent standard of living. To better know which Human Development Index factors have a significant effect on economic growth.

\section{REFERENCES}

Akman, B., \& A.H Sapha, D. (2018). Pengaruh Korupsi Terhadap Pertumbuhan Ekonomi di Indonesia. Journal Ilmiah Mahasiswa, 3(4), 531-538.

Al Qudah, A., Zouaoui, A., \& Aboelsoud, M. E. (2020). Does corruption adversely affect economic growth in Tunisia? ARDL approach. Journal of Money Laundering Control, 23(1), 38-54. https://doi.org/10.1108/JMLC-12-2018-0076

Anh, N. N., Minh, N. N., \& Tran-Nam, B. (2016). Corruption and economic growth, with a focus on Vietnam. Crime, Law and Social Change, 65(4-5), 307-324. https://doi.org/10.1007/s10611-016-9603-0

Arsyad, L. (2016). Ekonomi pembangunan. STIM YKPN.

Awad, A., Yussof, I., Ismail, R., \& Sarmidi, T. (2014). Economic growth and human development-what do time series data say for Sudan? Middle East Development Journal, 6(2), 151-174. https://doi.org/10.1080/17938120.2014.961329

Bardhan, P. (1997). Corruption and Development: A Review of Issues. Journal of Economic Literature, 35(3), 1320-1346.

Blackburn, K., Bose, N., \& Haque, M. E. (2011). Public expenditures, bureaucratic corruption and economic development. Manchester School, 79(3), 405-428. https://doi.org/10.1111/j.1467-9957.2009.02168.x

Chapra, U. (2007). Islam and Economic Development. In Islam and Economic Development. International
https://doi.org/10.2307/j.ctvkc674t 
Ertimi, B., Dowa, A., Albisht, E., \& Oqab, B. (2016). The impact of corruption on economic growth in OIC Countries. International Journal of Economics and Finance, 8(9). https://doi.org/10.5539/ijef.v8n9p91

Erum, N., \& Hussain, S. (2019). Corruption, natural resources and economic growth: Evidence from OIC countries. Resources Policy, 63(October 2019). https://doi.org/10.1016/j.resourpol.2019.101429

Ezkirianto, R., \& Alexandi, M. F. (2018). Analisis Keterkaitan Antara Indeks Pembangunan Manusia Dan Pdrb Per Kapita Di Indonesia. Jurnal Ekonomi Dan Kebijakan Pembangunan, 2(1), 14-29. https://doi.org/10.29244/jekp.2.1.1429

Fajar, M., \& Azhar, Z. (2018). Indeks Persepsi Korupsi dan Pembangunan Manusia Terhadap Pertumbuhan Ekonomi di Negara-Negara Asia Tenggara. Jurnal Ecogen, 1(3), 1-7. https://doi.org/10.24036/jmpe.v1i3.5114

Fanny, C., Liliane, B.-P., \& Jacques, F. (2011). Economists' Controversies about the Causality between War and Economic Cycles. In M. Chatterji, C. Bo, \& R. Misra (Eds.), Frontiers of Peace Economics and Peace Science (Vol. 16, pp. 85-97). Emerald Group Publishing Limited. https://doi.org/10.1108/S15728323(2011)0000016010

Feriyanto, N. (2019). The effect of the quality of human development factors on the rate of economic growth in Yogyakarta Special Province. International Journal for Quality Research, 13(1), 157-176. https://doi.org/10.24874/IJQR13.01-10

Fernández-Torres, Y., Gutiérrez-Fernández, M., \& Ramajo-Hernández, J. (2018). Business Regulation and Economic Growth: The Indirect Effect of Corruption in Latin America and the Caribbean. Journal of Developmental Entrepreneurship, 23(1). https://doi.org/10.1142/S1084946718500036

Ghozali, I. (2016). Aplikasi Analisis Multivariete Dengan Program IBM SPSS 23. UNIVERSITAS DIPONEGORO.

Ginting, C. K., Lubis, I., \& Mahalli, K. (2008). Pembangunan Manusia Di Indonesia. WAHANA HIJAU Jurnal Perencanaan \& Pengembangan Wilayah, 4(1), 17-24.

Gründler, K., \& Potrafke, N. (2019). Corruption and economic growth: New empirical evidence. European Journal of Political Economy, 60(December 2019). https://doi.org/10.1016/j.ejpoleco.2019.08.001

Hanif, S. (2018). Analisis Faktor Yang Mempengaruhi Indeks Pembangunan Manusia (IPM) Di Wilayah Karesidenan Surakarta Dalam Tinjauan Maqoshid Syariah [Universitas Muhammadiyah Surakarta]. http://eprints.ums.ac.id/id/eprint/63868

Hasibuan, I. H., Tanjung, H., \& Ibdalsyah. (2018). Analisis Maqashid Syariah Pada Indeks Pembangunan Manusia. Kasaba: Jurnal Ekonomi Islam, 11(1). https://doi.org/10.32832/kasaba.v11i1.2425

Ibrahim, C. (2020). Corruption, public debt and economic growth - evidence from developing countries. International Journal of Development Issues. https://doi.org/10.1108/IJDI-12-2019-0208

Irfan, N. (2016). Korupsi Dalam Hukum Pidana Islam. Amzah.

Izzah, N. (2014). Analisis Pengaruh Indeks Pembangunan Manusia (IPM) Dan Inflasi Terhadap Pertumbuhan Ekonomi di Propinsi Riau Tahun 1994-2013. At-Tijaroh, 1(2), 156-172. 
Javed, M., Abbas, S., Fatima, A., Azeem, M. M., \& Zafar, S. (2013). Impact of human capital development on economic growth of pakistan: A public expenditure approach. World Applied Sciences Journal, 24(3), 408-413.

Karlina, B. (2017). Pengaruh Tingkat Inflasi, Indeks Harga Konsumen Terhadap PDB di Indonesia Pada Tahun 2011-2015. Jurnal Ekonomika Dan Manajemen, 6(1).

Kawulur, A. F., Sumual, T. E. M., Kawulur, H., \& Hamenda, A. (2019). Human development and poverty reduction through economic growth. International Journal of Business and Management Science, 9(1), 19-31.

Machoski, E., \& de Araujo, J. M. (2020). Corruption in public health and its effects on the economic growth of Brazilian municipalities. European Journal of Health Economics, 21(5), 669-687. https://doi.org/10.1007/s10198-020-01162-3

Mahmood, H., \& Alkahtani, N. S. (2018). Human resource, financial market development and economic growth in Saudi Arabia: A role of human capital. Economic Annals-XXI, 169(1-2), 31-34. https://doi.org/10.21003/ea.V169-06

Mangaraj, B. K., \& Aparajita, U. (2020). Constructing a generalized model of the human development index. Socio-Economic Planning Sciences, 70(June 2020). https://doi.org/10.1016/j.seps.2019.100778

Maryaningsih, N., Hermansyah, O., \& Savitri, M. (2014). Pengaruh Infrastruktur Terhadap Pertumbuhan Ekonomi Indonesia. Bulletin of Monetary Economics and Banking, 17(1), 62-98. https://doi.org/10.21098/bemp.v17i1.44

Mohanty, S. K., Nandha, M., Turkistani, A. Q., \& Alaitani, M. Y. (2011). Oil price movements and stock market returns: Evidence from Gulf Cooperation Council (GCC) countries. Global Finance Journal, 22(1), 42-55. https://doi.org/10.1016/j.gfj.2011.05.004

Muharman, B., \& Maski, G. (2013). Analisis dinamis pengaruh instrumen fiskal terhadap pdb dan inflasi di indonesia.

Nawatmi, S. (2016). Pengaruh Korupsi terhadap Pertubumbuhan Ekonomi Studi Empiris Negara - Negara Asia Pasifik. Media Ekonomi Dan Manajemen, 31(1), 14-25.

OECD. (2020). Gross domestic product. Main Economic Indicators. https://doi.org/10.1787/54ace363-en

Prawoto, N., \& Basuki, A. T. (2020). The influence of macroeconomic variables, processing industry, and education services on economic growth in indonesia. Entrepreneurship and Sustainability Issues, 8(1), 1029-1040. https://doi.org/10.9770/jesi.2020.8.1(69)

Qamruzzaman, M., Jianguo, W., Jahan, S., \& Yingjun, Z. (2020). Financial innovation, human capital development, and economic growth of selected South Asian countries: An application of ARDL approach. International Journal of Finance and Economics, 1-22. https://doi.org/10.1002/ijfe.2003

Rachmadi, A. L. (2013). Analisis Pengaruh Utang Luar Negeri Terhadap Pertumbuhan Ekonomi Indonesia (Studi Kasus Tahun 2001-2011) [University of Brawijaya]. In Analisis Pengaruh Utang Luar Negeri Terhadap Pertumbuhan Ekonomi Indonesia (Studi Kasus 2001-2011). http://repository.ub.ac.id/106508/

Rietveld, P., \& Sunaryanto, L. T. (1994). 87 Masalah Pokok dalam Regresi Berganda. Andi Offset.

Sandholtz, W., \& Koetzle, W. (2000). Accounting for Corruption: Economic Structure, Democracy, and Trade. International Studies Quarterly, 44(1), 31-50. 
https://doi.org/10.1111/0020-8833.00147

Sasana, H. (2009). Analisis Dampak Pertumbuhan Ekonomi, Kesenjangan Antar Daerah Dan Tenaga Kerja Terserap Terhadap Kesejahteraan Di Kabupaten/Kota Provinsi Jawa Tengah Dalam Era Desentralisasi Fiskal. Jurnal Bisnis Dan Ekonomi, 16(1), 50-72.

Sasti, I. A. T. P., \& Latrini, M. Y. (2019). Pengaruh Alokasi Belanja Operasi dan Belanja Modal pada Indeks Pembangunan Manusia. E-Jurnal Akuntansi, 26(2). https://doi.org/10.24843/eja.2019.v26.i02.p29

Sen, A. (1985). Commodities and capabilities.

SESRIC. (2015). OIC Economic Outlook 2015.

Shabbir, G., Anwar, M., \& Adil, S. (2016). Corruption, political stability and economic growth. Pakistan Development Review, 55(4), 689-702.

Sukirno, S. (1985). Ekonomi Pembangunan Proses, Masalah dan Kebijaksanaan. Bima Grafika.

Sulaksono, A. (2015). Pengaruh Investasi Dan Tenaga Kerja Terhadap Pdb Sektor Pertambangan Di Indonesia. Jurnal Ilmiah Ekonomi Bisnis, 20(1), 16-24.

Suryana. (2000). Ekonomi Pembangunan: Problematika dan Pendekatan. Salemba Empat.

Susanto, A. B., \& Rachmawati, L. (2013). Pengaruh Indeks Pembangunan Manusia Dan Inflasi Terhadap Pertumbuhan Ekonomi Di Kabupaten Lamongan. Jurnal Pendidikan Ekonomi (JUPE), 1(3).

Todaro, M. (2013). Pembangunan Ekonomi Jilid 1 (11th ed.). PT. Gelora Aksara Pratama.

Tsaurai, K., \& Ndou, A. (2019). Infrastructure, Human Capital Development and Economic Growth in Transitional Countries. Comparative Economic Research, 22(1), 33-52.

Tseng, T.-Y. (2020). Corruption and Economic Growth: The Effects of Business Ethics. NTU Management Review, 30(1), 103-130. https://doi.org/10.6226/NTUMR.202004_30(1).0004

Umam, M. H. (2013). Pandangan Islam tentang Korupsi. Teosofi: Jurnal Tasawuf Dan Pemikiran Islam, 3(2). https://doi.org/10.15642/teosofi.2013.3.2.462-482

UNDP. (1990). Human Development Report 1990: Concept and Measurement of Human Development. http://hdr.undp.org/en/reports/global/hdr1990

Useche, A. J., \& Reyes, G. E. (2020). Corruption, competitiveness and economic growth: Evidence from Latin American and Caribbean countries 2004-2017. Journal Globalization, Competitiveness and Governability, 14(1), 95-115.

Viddy, A., Rafiqoh, \& Asniwati, B. (2019). The determinants of human development index and economic growth in Indonesia. International Journal of Scientific and Technology Research, 8(12), 661-665. 